\title{
MENEROPONG SPIRITUALITAS RUANG-CYBER DARI SUDUT HALMAHERA
}

\author{
(Jusuf Nikolas Anamofa)
}

\begin{abstract}
“Bersama semua 'facebookers' di segala masa dan tempat, mari kita mengikrarkan Pengakuan Iman Virtual: Aku percaya kepada Google, yang mahatahu dan murah hati memberi jutaan informasi; aku percaya kepada Internet yang telah menjadi karya penghubung roh-roh signal yang tak kelihatan tetapi penuh kuasa; aku percaya kepada roh Signal yang menjadi tumpuan harapan bagi umat manusia abad ini. Ketiganya yang esa, yang menjadi penuntun di kala suka dan duka."
\end{abstract}

(Steve Gaspersz, Facebook: 16 Mei 2013)

\section{Pengantar}

Bagaimana memaknai pernyataan di atas? Baiklah semua orang bertindak sebagai penafsir menurut sudut pandang masing-masing, namun saya menawarkan kepada pembaca untuk sedikit tenggelam dalam tulisan ini untuk menemukan beberapa aspek yang dapat dimanfaatkan untuk menafsirnya. Pernyataan itu muncul ketika ada diskusi tentang seperti apa tingkat literasi internet (e-literacy) rekan-rekan di salah satu group Facebook. Level e-literacy yang dijadikan panduan, yaitu: ${ }^{2}$

1. Level 0 , jika seorang individu sama sekali tidak tahu dan tidak peduli akan pentingnya informasi dan teknologi untuk kehidupan sehari-hari.

2. Level 1, jika seorang individu pernah memiliki satu dua kali pengalaman dimana informasi merupakan komponen penting untuk mencapai keinginan dan memecahkan masalah serta telah melibatkan teknologi informasi maupun komunikasi untuk mencarinya.

3. Level 2, jika seorang individu telah berkali-kali menggunakan teknologi informasi dan komunikasi untuk membantu aktivitasnya sehari-hari dan telah memiliki pola perulangan dalam penggunaannya.

4. Level 3, jika seorang individu telah memiliki standar penguasaan dan pemahaman informasi maupun teknologi yang diperlukannya serta konsisten mempergunakan standar sebagai acuan penyelenggaraan aktivitas sehari-hari.

5. Level 4, jika seorang individu telah sanggup meningkatkan secara signifikan kinerja aktivitas kehidupannya sehari-hari melalui pemanfaatan informasi dan teknologi.

\footnotetext{
${ }^{1}$ Struktur dari pengakuan iman virtual ini meniru struktur Pengakuan Iman Rasuli dalam Kekristenan, bandingkan dengan doa Cyberpunk's dalam Morten T. Højsgaard \& Margit Warburg (eds.) Religion and Cyberspace, (London \& NY: Routledge, 2005), hlm. 1, yang strukturnya meniru doa "Bapa Kami”.

${ }^{2}$ Istilah e-literacy diartikan sebagai kemampuan menggunakan perangkat teknologi informasi. Pengertian lainnya adalah sebagai komputer yang diintegrasikan dengan literasi informasi, literasi moral, literasi media, dan keterampilan belajar mengajar. Kemampuan e-literacy pada setiap individu memiliki pola yang berbeda sesuai dengan kebutuhan hidup dan kedewasaan masyarakat. Lihat, http://besar.blog.fisip-untirta.ac.id/2013/03/16/digitaldivide-dan-e-literacy/, dilihat pada 16 Mei 2013.
} 
6. Level 5, jika seorang individu telah menganggap informasi dan teknologi sebagai bagian tidak terpisahkan dari aktivitas sehari-hari serta secara langsung maupun tidak langsung telah mewarnai perilaku dan budaya hidupnya (menjadi bagian dari masyarakat internet).

Ada yang bertanya, "bagaimana kalau saya berada pada level selanjutnya dimana teknologi informasi dan komunikasi, termasuk informasi itu sendiri telah saya anggap sebagai agama karena teks-teksnya lebih sering saya renungkan daripada teks-teks tercetak kitab suci?"

Contoh lain, dari sekian banyak berita yang diturunkan media internet tentang pengaruh ruang-cyber, teknis dan non-teknis dalam bulan Mei 2013, ada beberapa yang menarik. Dua di antaranya adalah yang ditulis di dalam Tempo.co tanggal 17 Mei 2013 dengan tajuk "iPad bikin anak malas membaca”. Di sana dikemukakan temuan National Literacy Trust, suatu lembaga sosial di Amerika, yang mengungkapkan bahwa kemajuan anak-anak Amerika di dalam kelas menengah terhalang oleh penggunaan teknologi canggih. Lebih jauh dinyatakan tentang teman itu bahwa jumlah orang muda pembaca digital terus bertambah dari waktu ke waktu menggantikan jumlah orang-orang yang pertama kalinya membaca buku cetak. Kebiasaan itu, sebagaimana ditulis Tempo, bisa berpotensi merugikan kemampuan membaca mereka. Dinyatakan lagi, mereka yang membaca $e$-book setiap hari sangat kecil kemungkinan menjadi pembaca yang kuat dan sangat jarang menikmati bacaannya sendiri dibandingkan mereka yang membaca dari media cetak. Berita lainnya ditulis dalam Kompas.com tanggal 10 Mei 2013 dengan tajuk "Internet butuh tombol delete" yang mengangkat pendapat pimpinan eksekutif Google, Eric Schmidt. Menurut ulasan Kompas, informasi yang beredar di internet akan berada di sana selamanya dan hal itu dapat saja berakibat buruk bagi masa depan seseorang ketika informasi-informasi tentang keburukannya di masa lalu yang masih bisa diakses dalam internet, mempengaruhi posisi dan pekerjaannya di masa depan. Dinyatakan lagi, google misalnya menyimpan informasi di internet dalam waktu yang lama sehingga bisa diberikan kepada pihak berwenang apabila kelak diperlukan.

Dua hal utama terkait keberadaan ruang-cyber adalah: pertama, kehadirannya telah menjangkau hampir seluruh tempat - bahkan yang dianggap sudut terpencil - di dalam ruang fisik; kedua, kehadirannya telah menjangkau seluruh aspek kehidupan manusia baik sosial, budaya, politik, agama, maupun spiritualitas. Terkait dengan pernyataan-pernyataan dan pertanyaan di atas, tulisan ini hendak memfokuskan pembahasannya pada hal kedua, dimana asumsi dasarnya adalah ruang-cyber atau dikenal juga dengan internet ${ }^{3}$ telah mendapatkan tempatnya yang utama dalam setiap aspek kehidupan termasuk spiritualitas manusia, bahkan lebih jauh lagi, manusia telah menempatkan seluruh aspek kehidupan dirinya secara signifikan ke dalam ruang-cyber. Itulah paradox kehadiran ruang-cyber yang berhubungan dengan spiritualitas dan keberagamaan manusia ditengarai oleh Jeff Zaleski sebagaimana digambarkan oleh Yasraf Amir Piliang. ${ }^{4}$ Untuk lebih memahami makna kehadirannya dalam kerangka spiritualitas diperlukan upaya pencarian terus-menerus tanpa henti karena kemajuan teknologi komunikasi dan informasi yang memungkinkan segalanya terpikirkan seperti di atas pun

\footnotetext{
${ }^{3}$ Dalam bacaan Heidy Campbell, Ruang-Cyber adalah kata yang sinonim dengan Internet. Menurutnya, kata itu menunjukkan dunia "virtual" di mana teknologi dan fantasi bertemu melalui layar komputer para pengguna. Lihat artikel Heidy Campbell, Internet and Cyber Environment, dalam Encyclopedia of Religion, Communication, and Media, Danniel A. Stout, (ed.), (New York: Routledge, 2006), hlm. 177.

${ }^{4}$ Piliang dalam upaya menggambarkan pencarian akan Tuhan-Tuhan Digital mengemukakan tentang paradoxparadoks itu, antara lain, paradox antara ruang-cyber yang berfungsi sebagai media komunikasi keagamaan atau ia sebagai agama itu sendiri; paradox antara ruang-cyber sebagai penyalur daya spiritualitas atau ia sebagai spiritualitas itu sendiri; paradox antara hakekatnya sebagai pengingat kesucian tuhan atau ia sebagai "tuhan" itu sendiri. Piliang kemudian merekomendasikan Tulisan Jeff Zaleski, Spiritualitas Cyberspace: Bagaimana Teknologi Komputer Mempengaruhi Kehidupan Keberagamaan Manusia yang dianggapnya sangat memikat dalam menggambarkan panorama cyberspace yang penuh dengan paradox itu. Lihat http://books.google.com/books?isbn=9796685221, dilihat pada 13 Mei 2013.
} 
bergerak tanpa henti. Salah satu jalan dari sekian banyak jalan pemaknaan adalah dengan menstudikan spiritualitas (dalam) ruang-cyber. Asumsi di atas menjadi arah untuk mengelaborasi kontribusi-kontribusi yang pernah diberikan dalam diskursus tentang ruangcyber, khususnya tentang kemungkinan-kemungkinan metodologis yang dapat menjadi panduan terbuka bagi para teologi dan mahasiswa teologi menstudikan cyber-space sebagai salah satu konteks berteologi.

Tulisan ini disusun dalam segala keterbatasan referensi (fisik) dan kekayaan sumber-sumber (digital) yang dapat diakses dari Tobelo, kota Kabupaten Halmahera Utara. Penekanan tempat fisik adalah upaya untuk menyatakan bahwa konteks tempat (ruang fisik) dengan segala kompleksitasnya masih berperan sebagai latar belakang, sekalipun untuk menulis tentang konteks tempat dalam perspektif ruang-cyber.

Tobelo secara fisik dapat dijangkau melalui udara, darat, dan laut. Perjalanan dari Kota Ternate yang masih menjadi pusat pemerintahan Provinsi Maluku Utara saat ini dapat ditempuh selama empat puluh lima menit lewat laut dan kurang lebih empat jam melalui darat. Selama empat jam Perjalanan darat itu, kurang lebih satu jam terputus dari akses komunikasi ke dunia luar karena wilayah-wilayah tertentu tidak terjangkau layanan telekomunikasi. Dapat dibayangkan bagaimana mencapai kota ini secara fisik.

Namun ketika tiba di Tobelo, jauhnya jangkauan fisik itu seolah tidak berarti karena geliat pemanfaatan teknologi informasi dan komunikasi yang cukup baik. Beberapa titik telah terlayani oleh jaringan $3 \mathrm{G}$, walaupun sebagian besar wilayah masih dilayani $2 \mathrm{G}$. kampus-kampus yang ada pun telah terlayani internet 24 jam, baik lewat jaringan kabel maupun nirkabel. Internet telah menjadi bagian tak terpisahkan dari kehidupan sebagian penduduk kota yang berkepentingan dengannya. Di bidang pendidikan, kehadiran internet adalah "anugerah" tersendiri di tengah kondisi kurangnya referensi-referensi fisik terbaru dari berbagai disiplin ilmu. Geliat di bidang ekonomi dan politik pun menjadikan internet sebagai kebutuhan berkomunikasi, saling berbagi informasi, berbisnis, dan berkampanye. Di bidang keagamaan, para teologi terutama para pendeta yang harus selalu siap dengan materi-materi khotbah dan ceramah begitu mudahnya memperoleh referensi-referensi dari internet. Celakanya, internet juga menjadi ruang saling menyalahkan, menyesatkan, menghujat, memfitnah, dan sebagainya yang berdampak buruk pada hubungan-hubungan antar manusia, baik dalam ruang-cyber (cyberspace) maupun ruang fisik. Berdasarkan kenyataan-kenyataan amatan sementara itu, dapat dibangun hipotesis bahwa dari waktu ke waktu, terjadi peningkatan e-literacy pada penduduk Kota Tobelo, baik dari sisi jumlah maupun tingkatan levelnya secara signifikan. ${ }^{5}$

Gambaran singkat itu hanyalah potret satu sisi kehidupan Pulau Halmahera yang semakin menggeliat untuk menghubungkan segala aspek kehidupannya secara global. Di sisi lain, Pulau Halmahera juga menjadi rumah bagi sebagian kecil penduduk yang - bahkan oleh sebagian penduduk di Halmahera sendiri - masih dikategorikan sebagai "masyarakat terpencil" atau "suku terasing", yaitu mereka yang disebut dengan "orang Togutil". ${ }^{6}$ Walaupun pembedaan ruang-ruang hidup antara dua kenyataan itu tidak bisa hitam putih karena sesungguhnya ada jalinan-jalinan interaksi fisik di sana, tetapi dalam pemanfaatan ruang-cyber, perbedaannya cukup tegas, untuk mengatakan bahwa ada "kesenjangan digital" yang begitu nyata.

\footnotetext{
${ }^{5}$ Studi empiris lebih lanjut diperlukan untuk menguji hipotesis itu dengan mengelaborasi lagi apa saja faktor-faktor yang berkontribusi dan bagaimana faktor-faktor itu berkontribusi terhadap tingkat $e$-literacy masyarakat Tobelo.

${ }^{6}$ Dengan menggunakan kata kunci "suku Togutil" untuk mencari di internet, khususnya di mesin pencari google saja, ditemukan 14.000 halaman yang memuat kata kunci itu. Isinya dapat berupa deskripsi, gambar, atau film.

${ }^{7}$ Bukan saja kesenjangan di bidang ekonomi, pendidikan, politik, dan lainnya, tetapi juga ada kesenjangan digital (digital divide). Kesenjangan digital adalah kenyataan ketidakmerataan ekonomi antar komunitas dalam pengertian akses untuk menggunakan teknologi informasi dan komunikasi. Kasus seperti di Halmahera menunjukkan bahwa kesenjangan digital dapat terjadi antara satu individu dengan individu lain, rumah-rumah tangga, kelompok-
} 
Asumsi dasar tulisan ini telah dijelaskan di atas. Pertanyaan pengaruh untuk lebih memfokuskan perhatian adalah: "Sejauhmana spiritualitas (dalam) ruang-cyber dapat distudikan atau diteliti oleh para teologi dan mahasiswa teologi di Tobelo dan di mana saja yang tertarik terhadap isu-isu ini?" "Apa saja kemungkinan-kemungkinan metodologis yang tersedia, yang dapat mengarahkan studi atau penelitian semacam itu?" Kedua pertanyaan itu membimbing kepada upaya menemukan dasar sebelum masuk dalam pertanyaan yang ketiga, yang belum menjadi bagian bahasan tulisan ini, yaitu: "Bagaimana menstudikan atau meneliti spiritualitas (dalam) ruang-cyber?"

\section{Apa Itu Spiritualitas?}

Bagi sebagian orang, spiritualitas masih erat dihubungkan dengan agama-agama secara institusional. Tetapi bagi sebagian lainnya, spiritualitas adalah fenomena kehidupan manusia yang jauh melampaui keberagamaan secara institusional. Tentang definisi spiritualitas, ada berbagai pendapat dan perspektif tentangnya. Di sini akan dikemukakan pendapat Sandra M. Schneiders sebagaimana disitir oleh David B. Perrin, yang bergelut di bidang spiritualitas Kristen, sebagai berikut:

"Spiritualitas adalah pengalaman kehidupan manusia yang dapat didefinisikan sebagai suatu keterlibatan sadar dalam proyek integrasi kehidupan melalui transendensi-diri ke arah nilai tertinggi yang seseorang terima. Definisi spiritualitas ini dapat menolong untuk menggambarkan spiritualitas-spiritualitas yang tidak memasukan kepercayaan kepada Allah, yang mana tidak perlu ditolak. Contoh, 'nilai tertinggi yang diyakini seseorang' dapat menjadi Allah."

Sebelum tiba pada definisi itu, Perrin mengemukakan empat elemen penting yang membentuknya, yaitu:

1. Spiritualitas adalah kapasitas fundamental manusia yang dikenal sebagai hakekat spiritual manusia yaitu kapasitas pencaharian makna, nilai, dan tujuan hidup;

2. Spiritualitas adalah pencarian tentang bagaimana setiap individu tumbuh dalam intimitas, ketergantungan, dan hubungan yang saling berbagi dengan orang lain dan dunia secara keseluruhan;

3. Spiritualitas adalah suatu realitas kehidupan yang terbentuk ke dalam pilihan-pilihan bagaimana seseorang menjalani kehidupannya, apakah ia seorang atlit, pendidik, dan sebagainya;

4. Spiritualitas juga dihubungkan dengan upaya meneliti bagaimana orang menghidupi kehidupannya sehubungan dengan ketiga aspek di atas. Dengan demikian, ketiga aspek spiritualitas di atas adalah kategori-kategori spiritualitas yang dapat diteliti dalam konteks apapun. ${ }^{9}$

Ketika menghubungkan definisi spiritualitas di atas dengan kehidupan secara umum, Perrin menghubungkannya dengan hal-hal paling penting dalam kehidupan manusia, yaitu: kehidupan dan kematian. Di antara dua kutub itulah spiritualitas manusia dapat dimengerti - apakah dihubungkan dengan keyakinan kepada Allah atau tidak - sebagai perjuangan dengan sejumlah misteri yang menghadirkan pertanyaan-pertanyaan mendalam tentang kehidupan manusia. Menurutnya, dunia kehidupan manusia adalah dunia yang penuh dengan nilai-nilai, keyakinan-

kelompok masyarakat, yang berada pada wilayah-wilayah geografi yang berbeda. Lihat penjelasan tentang digital divide dalam http://en.wikipedia.org/wiki/Digital_divide, dilihat pada 16 Mei 2013.

${ }^{8}$ David B. Perrin, Studying Christian Spirituality (New York: Routledge, 2007), hlm. 20.

${ }^{9}$ Perrin, (2007: 18-19) 
keyakinan, kebenaran-kebenaran, harapan-harapan, dan hasrat-hasrat, yang membuat manusia mesti bergerak melampaui apa yang dapat dilihat dan disentuh. Terhadap itu, aspek spiritualitas manusia sajalah yang terbuka bagi pencarian kebenaran otentik dalam seluruh pengalaman kehidupan, dari seluruh nilai-nilai normatif yang ada, terhadap seluruh pertimbangan nalar yang dapat membimbing manusia ke arah penentuan diri (self-determination). Berdasarkan hal itu, spiritualitas dapat dimengerti sebagai realitas keseharian yang dapat semua orang bagi dalam kehidupannya. ${ }^{10}$

Pendapat Perrin di atas didasari oleh gagasan Bernard Lonergan (1904-1984) tentang petunjuk mendasar bagi kehidupan manusia. Lonergan mengemukakan empat hal paling mendasar dalam kehidupan manusia, yang dinamainya "ajaran transcendental", yaitu: menjadi penuh perhatian (terhadap fakta); menjadi cerdas (dengan ide-ide); menjadi rasional (dengan fakta-fakta); dan menjadi bertanggung jawab (dengan nilai-nilai). Ajaran-ajaran itu tentu saja bukan aturan tetapi lebih sebagai norma-norma internal bagi setiap orang yang hidup dalam realitas. Dinyatakan lagi bahwa istilah "otentisitas" digunakan oleh Lonergan untuk menunjuk kualitas spiritualitas orang-orang yang mengikuti norma-norma itu. ${ }^{11}$

Spiritualitas dalam kehidupan setiap hari tentu saja tidak melulu hadir sebagai hal yang otentik dan membebaskan manusia dari pandangan sempat yang hanya memusatkan perhatian pada dunia pribadi yang narsistik. Spiritualitas juga dapat hadir dalam kepentingan-kepentingan dangkal yang kalau tidak dimengerti secara hati-hati dapat membimbing manusia ke dalam tindakan-tindakan penghancuran baik terhadap sesama maupun dunia secara keseluruhan. Spiritualitas seperti itu bukanlah spiritualitas yang otentik.

Kehadiran spiritualitas, baik yang otentik maupun yang tidak, didukung oleh berbagai faktor. Salah satunya adalah media sebagai "pasar spiritualitas". Kavanaugh menyatakan bahwa kita adalah konsumen dari ide-ide, makanan-makanan cepat saji (junk foods), gadget plastik keluaran terbaru yang sebenarnya bukan merupakan kebutuhan, bahkan kita "mengkonsumsi" orang-orang lain. Segala sesuatu secara potensial adalah komoditas yang dapat dijual karena kebutuhan dan keinginan manusia yang terus-menerus mengalami kebaruan. Bukan saja bendabenda material yang dapat menjadi komoditas, segala sesuatu yang abstrak seperti pertemanan, keintiman, cinta, penghargaan, kebahagiaan, adalah obyek-obyek yang dapat dibeli dan dikonsumsi. ${ }^{12}$ Itu berarti, spiritualitas juga dapat menjadi komoditas yang diperjualbelikan. Hal itu nampak dengan begitu banyak buku, Majalah, Koran, dan lain-lain yang berisi ide-ide spiritual, baik otentik maupun tidak, yang beredar di pasaran. Apalagi dengan tersedianya ruang baru dalam kehidupan manusia, yaitu ruang-cyber yang menyediakan tempat tak terbatas dan kaya akan segala jenis informasi, termasuk tempat jual beli ide dan gagasan. Di ruang baru itu, konsep-konsep spiritualitas manusia dari segala abad dan tempat, otentik atau tidak, semakin mudah diperoleh. Konsep-konsep itu dapat menjadi penggerak bagi tindakan-tindakan manusia, entah membebaskan atau menghancurkan.

Bagaimana dengan spiritualitas Kristen? Perrin menyatakan bahwa spiritualitas dapat dikatakan sebagai spiritualitas Kristen ketika Allah yang diyakini umat Kristen menjadi keyakinan utama dalam kehidupan seseorang; kehidupan yang saling berinteraksi merujuk pada kehidupan Yesus; dan 'spirit' dalam spiritualitas Kristen diidentifikasi sebagai Roh Kudus. ${ }^{13}$

Ia kemudian mencatat beberapa definisi kerja yang disampaikan para pemikir di bidang spiritualitas Kristen sebagai berikut:

\footnotetext{
${ }^{10}$ Perrin, (2007:20)

${ }^{11}$ Lihat catatan ke-7 dari catatan-catatan Perrin dalam pembahasannya tentang Spiritualitas, Perrin (2007: 54).

${ }^{12}$ Perrin, (2007: 24)

${ }^{13}$ Perrin, (2007: 26)
} 
“Apapun yang mungkin dinyatakan tentang spiritualitas yang cenderung biblis, kematangan spiritualitas atau pemenuhannya sangat melibatkan seluruh aspek manusia tubuh, pikiran dan jiwa, tempat, hubungan-hubungan - dalam hubungan dengan seluruh ciptaan sepanjang waktu. Spiritualitas biblis meliputi seluruh aspek kehidupan manusia dalam totalitas eksistensinya di dalam dunia, bukan beberapa bagian atau potonganpotongan atau kejadian dalam kehidupan seseorang." ${ }^{\prime 4}$

"Spiritualitas (paling kurang dalam konteks Kristen) adalah istilah yang berguna untuk menggambarkan bagaimana, baik secara individual maupun kolektif, kita secara pribadi menjadikan keyakinan-keyakinan tradisional Kristen tentang Allah, kemanusiaan dan dunia, dan mengekspresikan keyakinan-keyakinan itu dalam pengertian sebagai dasar bagi sikap, gaya hidup, dan aktifitas kita." 15

"Spiritualitas adalah pengalaman kehidupan manusia yang dapat didefinisikan sebagai suatu keterlibatan sadar dalam proyek integrasi kehidupan melalui transendensi-diri ke arah nilai tertinggi yang seseorang terima. Dalam spiritualitas Kristen, kategori-kategori formalnya dikhususkan dalam pengertian Kristen: horizon dari nilai tertinggi adalah ketritunggalan Allah yang diwujudkan dalam Yesus Kristus dan proyek yang dimaksud adalah keterlibatan dalam kehidupan dari misteri kebangkitanNya di dalam konteks komunitas gereja melalui pemberian Roh Kudus."

"Spiritualitas Kristen adalah ekspresi dari keyakinan tertinggi seseorang dalam kehidupan setiap hari dalam komunitas, dicirikan oleh keterbukaan untuk berbagi kasih Allah, diri sendiri, sesama, dan dunia melalui Yesus Kristus dan di dalam kekuatan Roh Kudus."17

Jelas dari definisi-definisi kerja itu beberapa elemen dasar spiritualitas Kristen, yaitu:

1. Spiritualitas Kristen melibatkan seluruh aspek kehidupan manusia.

2. Spiritualitas Kristen didasarkan pada ketritunggalan Allah di dalam Yesus Kristus dan dalam kekuatan Roh Kudus.

3. Spiritualitas Kristen diekspresikan dalam kehidupan setiap hari.

\section{Apa itu Ruang-Cyber?}

Kalau si penyanyi nyentrik Mbah Surip (alm.) membuat lirik lagu bangun tidur, tidur lagi, maka dalam kenyataan ruang-cyber tak ada waktu untuk "tidur lagi". Yang terjadi adalah "bangun tidur, nge-net lagi, update status media sosial lagi, online lagi", seperti lirik lagunya Saykoji. Walaupun gambaran itu hanya amatan di sekeliling, bahkan terjadi pada diri penulis sendiri, tetapi karena berhubungan dengan ruang-cyber yang telah merambah secara global, maka dapat ditarik kesimpulan a priori bahwa itu adalah fenomena global saat ini.

Jadi, apa itu ruang-cyber? Michael Benedikt mengkonfirmasi sepuluh definisi ruang-cyber di dalam artikelnya. ${ }^{18}$ Definisi-definisi Senada pun dikemukakan oleh para pemikir lainnya. Dari berbagai definisi itu, dapat ditemukan beberapa hal terkait istilah ruang-cyber sebagai berikut:

1. Kata cyber berakar pada istilah Yunani yang berarti pengaruh, gubernur, sopir, atau pilot. $^{19}$

${ }^{14}$ Definisi kerja menurut Stringfellow, Perrin, (2007: 31)

${ }^{15}$ Definisi kerja menurut Philip Sheldrake, Perrin, (2007: 31)

${ }^{16}$ Definisi kerja menurut Sandra M. Schneiders, Perrin, (2007: 31)

${ }_{18}^{17}$ Definisi kerja menurut Elizabeth Dreyer, Perrin, (2007: 31)

18 Michael Benedikt, Introduction to Cyberspace: First Steps (1991), dalam https://pdfs.semanticscholar.org/8517/59b84ee29d8fd9ee66b90316e4bc08406e15.pdf, dilihat pada 17 Mei 2013.

${ }^{19}$ Greg Wiegand (ed.) Encyclopedia of Technological Terms (Indianapolis: Que Publishing, 2002), hlm. 162, juga Heidy Campbell, Internet and Cyber Environment (New York: Routledge, 2006), hlm. 177. Campbell secara 
2. Kata cyberspace berasal dari bahasa Latin "kubernan", yang artinya menguasai atau menjangkau. ${ }^{20}$ Secara luas dapat didefinisikan sebagai keterjalinan total manusia melalui komputer-komputer dan telekomunikasi tanpa batasan-batasan fisik, ${ }^{21}$ suatu jaringan kerja global yang multi dimensi dan artifisial. ${ }^{22}$ Kata ini seringkali digunakan untuk menunjuk kepada internet di mana teknologi dan fantasi berjumpa dalam layar komputer pengguna. ${ }^{23}$ Ruang-cyber adalah ruang immaterial, untuk membedakannya dengan ruang material sebagaimana yang ditempati secara fisik oleh obyek-obyek material seperti tubuh manusia dan benda-benda material lainnya. ${ }^{24}$

3. Istilah cyberspace pertama kali digunakan oleh William Gibson dalam novel fiksi ilmiahnya Neuromancer (1984). Dalam halaman 69 novel itu tertulis:

"Cyberspace. A consensual hallucination experienced daily by billions of legitimate operators, in every nation, by children being taught mathematical concepts .... A graphic representation of data abstracted from banks of every computer in the human system. Unthinkable complexity. Lines of light ranged in the nonspace of the mind, clusters and constellations of data. Like city lights, receding ....,25

Bagi penulis Neuromancer, ruang-cyber sangat dihubungkan dengan pengalaman setiap hari dalam halusinasi yang disepakati. Dari pemahaman sebagai halusinasi di atas, wajarlah kalau padanan istilah cyberspace dalam bahasa Indonesia adalah "dunia maya". 26

Ruang seperti apa ruang-cyber itu? Pertanyaan ini sangat penting bagi seluruh upaya manusia memahami seluk beluk keterlibatannya di dalam ruang-cyber karena ruang (dan waktu) adalah konsep paling mendasar. Untuk memahaminya, konsep ruang (space) perlu dijelaskan lebih dahulu. Istilah "ruang" dalam kamus diartikan sebagai sela-sela antara dua titik; rongga yang terbatas atau terlingkung oleh bidang; rongga yang tidak terbatas, tempat segala yang $a d a .^{27}$

Pierre Gernon membedakan tiga jenis ruang dalam sketsa ontologi ruangnya. Ketiga jenis ruang itu adalah: (1) ruang abstrak, contohnya ruang dalam model dan struktur matematika adalah sesuatu yang abstrak; (2) ruang fisik adalah ruang tempat beradanya segala benda dalam realitas; (3) ruang virtual adalah ruang tempat beradanya segala benda yang tidak dapat ditempatkan dalam realitas. Ia membagi ruang virtual dalam tiga kategori, yaitu: (a) ruang simulacra yang mana merupakan model-model atau reproduksi-reproduksi dari ruang-ruang fisik yang actual. Contoh, versi virtual dari Museum British adalah ruang simulacra; (b) ruang fiksional adalah ruang virtual yang dibangun dengan mengabaikan kesamaan-kesamaan terperinci dengan ruang fisik. Contoh, dunia virtual dalam suatu permainan (game) komputer; (c)

terperinci menyebutkan bahwa istilah cyber menjadi ide dasar Internet sebagai fasilitasi transisi antara yang real dan yang virtual. Dapat dimengerti berdasarkan makna katanya, yaitu pengaruh atau sopir yang dapat mengantar seseorang dari satu titik ke titik lainnya.

${ }^{20}$ Buick \& Joran Jevic, Mengenal Cyberspace For Beginners (Bandung: Mizan, 1997), hlm. 4.

${ }^{21}$ Wiegand, hlm. 163.

${ }^{22}$ Sebagaimana digambarkan oleh Michael Benedikt yang dikutip oleh John Mabry dalam artikelnya, Cyberspace and the Dream of Teilhard de Chardin, dalam http://www.watershedonline.ca/roots/chardin/chardin2.html, dilihat pada 13 Mei 2013.

${ }^{23}$ Campbell.

${ }_{24}$ Lihat, Margareth Wertheim, Is Cyberspace a Spiritual Space?, dalam http://www.cybersociology.com/files/7 wertheim.html, dilihat pada 17 Mei 2013.

${ }^{25}$ Theo Zijderveld, Cyberpilgrims: The Construction of Spiritual Identity in Cyberspace (Research Master Theology, 2008), hlm. 10-11. Dapat diakses secara online di http://www.theozijderveld.com/cyberpilgrims/_Cyberpilgrims theo zijderveld.pdf, dilihat pada 12 Mei 2013.

Selain itu, dapat juga ditemukan dalam beberapa website berupa./

${ }^{26}$ http://id.m.wikipedia.org/wiki/Daftar_istilah_Internet_Indonesia.htm, dilihat pada 12 Mei 2013.

27 Pengertian "ruang” dalam KBBI Android. 
ruang ersatz adalah ruang virtual tambahan bagi ruang fisik. Contoh, Perpustakaan virtual (tempat Penyimpanan dokumen-dokumen yang ditampilkan dalam suatu cara penempatan tertentu). ${ }^{28}$

Rebecca Bryant dengan cukup rinci memberikan gambaran tentang ruang dalam hubungannya dengan ruang-cyber. ${ }^{29}$ Ia bertitik tolak dari arti ruang sebagai "media tiga dimensi yang di dalamnya segala hal fisik ada." Menurutnya, ada empat sub-konsep yang dapat digunakan untuk memahami tentang konsep ruang, yaitu: tempat, jarak, ukuran, dan arah. "Tempat" digunakan untuk mengetahui di mana segala sesuatu berada dalam hubungan dengan diri manusia dan hal-hal lainnya agar dapat ditemukan, diabaikan, atau dijadikan bagian dalam peta mental tentang suatu wilayah. "Jarak" digunakan untuk mengetahui seberapa jauh suatu tempat dari tempat yang lain atau suatu hal dari hal yang lain agar dapat ditentukan bagaimana cara atau berapa lama tempat atau hal itu bisa dicapai. "Ukuran" digunakan untuk mengetahui berapa besar atau berapa banyak hal yang dapat dipindahkan dari suatu tempat ke tempat tertentu. "Arah" digunakan untuk mengetahui jalan yang benar untuk tiba di suatu tempat.

Bryant menyatakan bahwa ruang-cyber, sama dengan ruang fisik, juga dapat dimengerti berdasarkan empat sub-konsep di atas. "Tempat" digunakan untuk mengetahui di server mana suatu website berada, alamat email mana yang harus dikirimi pesan, ruang-ruang chat mana yang harus dimasuki. "Jarak" digunakan untuk mengetahui banyaknya loncatan yang dibutuhkan informasi di antara komputer-komputer, satelit, server, untuk tiba pada tujuannya. Dengan itu dapat diketahui berapa lama suatu website dapat terbaca di layar komputer. "Ukuran" digunakan untuk mengetahui besarnya atau banyaknya isi yang terkandung dalam suatu website. Selain itu, digunakan juga untuk mengetahui besarnya file yang dapat dikirimkan ke suatu alamat email atau yang harus diunduh dari website. Sama dengan jarak, ukuran juga menentukan berapa waktu yang dibutuhkan untuk mendapatkan suatu hal dari suatu tempat dalam pengertian ruang-cyber. "Arah" digunakan untuk mengetahui ke mana saja informasi-informasi bisa dicari dan diperoleh. Hal yang tersedia untuk itu dikenal dengan nama web browsers.

Berdasarkan pembahasan Gernon dan Bryant, hal yang membedakan antara ruang fisik dengan ruang-cyber adalah:

1. Ruang fisik adalah ruang alami, tidak diciptakan oleh manusia. Dengan demikian tidak tergantung dan tidak dapat dikontrol oleh manusia sebagai salah satu obyek di dalamnya, sementara ruang-cyber adalah ruang artifisial, diciptakan oleh manusia dan keberadaannya tergantung dan dapat dikontrol oleh manusia.

2. Ruang fisik, keberadaannya tidak tergantung pada ruang-cyber, sebaliknya keberadaan ruang-cyber sangat tergantung pada ruang fisik. Ketergantungan ruang-cyber pada ruang fisik adalah pada adanya perangkat keras (hardware) berupa komputer-komputer, kabel-kabel, antena-antena, satelit-satelit, juga perangkat lunak (software) yang

\footnotetext{
${ }^{28}$ Untuk memahami kerangka pikir ontologi ruang Gernon dengan lebih jelas, dapat dilihat dalam Pierre Gernon, $A$ Sketch of an Ontology of Spaces, http://kmi.open.ac.uk/events/onespace08/docs/onespace2008_submission_2.pdf, dilihat pada 12 Mei 2013.

${ }^{29}$ Rebecca Bryant, What Kind of Space is Cyberspace, dalam Minerva, An Internet Journal of Philosophy 5 (2001), hlm. 138-55. Dapat dilihat di http://www.minerva.mic.ul.ie/vol5/cyberspace.pdf, dilihat pada 12 Mei 2013.

${ }^{30}$ Yasraf Amir Piliang mempersoalkan jarak dalam pengertian pelipatan ruang dan waktu. Baginya, melipat waktu adalah memperpendek jarak waktu (chronos) dengan meningkatkan kecepatan atau memperpendek Durasi. Melipat ruang artinya memperkecil jarak ruang dengan cara memperpendek waktu tempuh di dalam ruang itu. Melipat ruang adalah sekaligus melipat waktu dan sebaliknya. Dalam kenyataan teknologi transportasi, komunikasi, dan informasi yang semakin maju, sesungguhnya ruang telah ditaklukkan oleh kekuatan waktu sehingga jarak bukan lagi persoalan. Untuk itu, ia menyatakan konsep "real time", bahwa ketika ruang dimengerti sebagai jarak antara dua tempat, maka yang nyata dalam konteks kemajuan teknologi informasi dan komunikasi saat ini hanyalah waktu. Lihat Piliang, Dunia Yang Dilipat: Tamasya Melampaui Batas-Batas Kebudayaan (ed. 3), (Bandung: Matahari, 2010), hlm. 49-65.
} 
tersimpan di dalam perangkat keras yang hanya mungkin ada di dalam ruang fisik. Tanpa hardware dan software yang memungkinkan adanya ruang-cyber, ruang fisik tetap ada.

Penjelasan tentang ruang-cyber yang dapat dimengerti dengan menggunakan sub-sub konsep pemahaman terhadap ruang fisik mempertegas Asumsi awal tulisan ini bahwa aspekaspek kehidupan manusia pun dapat berlangsung di dalam ruang-cyber.

Untuk memahami lebih jauh tentang internet atau ruang-cyber, dalam hal ini pihak-pihak yang terlibat di dalam internet, Bakardjieva dalam "teknobiografi"nya Mengidentifikasi dua pihak yang sangat berhubungan erat dengan internet, yaitu masyarakat internet dan profesional internet. Masyarakat internet adalah user atau pengguna internet, yaitu orang-orang biasa, lakilaki dan perempuan, yang tidak termasuk dalam kategori orang-orang yang profesional di bidang internet. Profesional internet adalah para teknisi, programmer, desainer, bidang pemasaran, dan pelayanan dalam teknologi jaringan komputer, para pengambil keputusan dalam industri internet, dan sebagainya. Sebagai pengguna, masyarakat internet hanya memanfaatkan layananlayanan yang telah disediakan oleh para profesional internet untuk kepentingan-kepentingan dalam kehidupannya. ${ }^{31}$

\section{Spiritualitas (dalam) Ruang-Cyber}

Meskipun bagi sebagian orang, spiritualitas adalah fenomena kehidupan manusia yang jauh melampaui keberagamaan institusional sebagaimana ditengarai Perrin di atas, tetapi dalam tulisan ini, agama (dan teologi), terutama kekristenan, dipilih sebagai sudut pandang. Hal itu lebih disebabkan posisi penulis sebagai orang yang pernah belajar teologi formal dan beraktifitas di lingkungan pendidikan teologi Kristen. Dengan demikian, ketika tiba pada titik ini, spiritualitas yang dimaksudkan adalah spiritualitas Kristen.

Bagian ini ditulis ketika umat Kristen sementara merayakan "kenaikan" Yesus Kristus ke sorga, kemudian merayakan hari "keturunan" Roh Kudus. Dari kedua perayaan itu, nampak konsep teologi Kristen tentang tempat dan waktu dari Sang Allah, yaitu sorga dan kekekalan. Sorga digambarkan sebagai suatu tempat yang berada di atas (langit?), oleh karena itu, Yesus Kristus terangkat ke atas, ke langit, ke sorga. Begitu juga Roh Kudus dikabarkan "turun", kata yang digunakan untuk menggambarkan aktifitas bergerak dari atas ke bawah. Lihat juga bagian kitab suci yang mengisahkan tentang pembaptisan Yesus dan langit terbuka kemudian suara Allah terdengar, serta bagian-bagian lain yang memberikan gambaran tentang letak sorga sebagai tempat kediaman Allah.

Sorga yang kekal bukanlah topik bahasan bagian ini, tetapi membahasnya (membahasakannya) di sini hendak menunjukkan bahwa terhadap Allah pun konsep ruang dan waktu berlaku (walaupun konsep itu dimaknai melampaui ruang dan waktu manusia, "sorga yang kekal", melampaui "dunia yang fana"). Byrne dalam salah satu seri kuliahnya menulis tentang "Doa Bapa kami yang di sorga" hendak menunjukkan bahwa Allah berada di suatu tempat khusus (somewhere), bukan di berbagai tempat (everywhere), atau tidak berada di suatu tempat pun (nowhere). ${ }^{32}$ Baginya, itu adalah konsep teologi tradisional yang hidup dalam dunia

\footnotetext{
${ }^{31}$ Bakardjieva menggunakan istilah teknobiografi karena karya yang ditulisnya didasarkan atas pengalamannya sebagai pengguna (user) internet. Lihat, Maria Bakardjieva, Internet Society: The Internet in Everyday Life, (London: Sage Publications, 2005), sebagaimana disitir dalam Analisis Filosofis Terhadap Teoblogis: Relevansinya Sebagai Penyeimbang Moralitas dalam Masyarakat Internet, Jusuf Nikolas Anamofa, UNIERA - Jurnal Ilmiah Lintas Ilmu Vol. 1, No. 2, Agustus 2012, hlm. 101-102.

${ }^{32}$ Menarik untuk menyimak pertanyaan Lavinia Byrne, “dimanakah Allah berada?” dan penjelasannya dalam materi kuliahnya yang diberi judul: God in Cyberspace.
} 
pre-saintifik. Konsep itu bermasalah ketika model sains memberikan gambaran tentang ruang (khususnya langit) yang tak terbatas. Pertanyaan sederhana yang dapat diajukan dalam kacamata sains adalah kemanakah Yesus terangkat dalam model ketakterbatasan ruang itu? Di langit manakah letak sorga itu kalau langit sendiri tak terbatas? Pada titik itu, muncul pendapat teologi tentang ruang spiritual yang melampaui ruang fisik tempat hidup manusia. Ruang itu adalah ruang yang suci yang memungkinkan kehadiran Allah di dalam dunia dan di tengah-tengah komunitas Kristen khususnya dengan caranya yang misterius dan unik.

Dari apa yang disampaikan Byrne di atas dapat ditangkap suatu maksud yang hendak menjelaskan bahwa konsep teologi Kristen tentang tempat dan waktu pun berubah seiring perkembangan ilmu yang mempengaruhi perubahan pandangan dunia. Pada masa pre-saintifik, sorga yang kekal itu dianggap berada di atas langit, di antara bintang-bintang, ada di atas sana. Pada masa sains mulai berkembang, sorga yang kekal itu dimaknai dalam pengertian yang spiritual, ada di sini, di dunia ini, tetapi bukan dunia materi. Bagaimana dengan konsep sorga yang kekal pada masa kini, di mana realitas virtual telah dianggap sebagai salah satu realitas bagi kehidupan manusia? Apakah sorga yang kekal itu juga melingkupi kenyataan virtual, ruang-cyber?

Bacaan terhadap pendapat Byrne menemukan kemungkinan itu dalam kerangka perkembangan konsep-konsep teologi sesuai tuntutan zaman di mana manusia hidup. Baginya, keberadaan ruang-cyber menuntut suatu jalan baru menempatkan Allah dalam ruang dan waktu, sama seperti ketika dunia sains menggantikan dunia pre-saintifik di atas. Jika ruang-cyber dapat dimasuki manusia, mengapa Allah tidak? Hanya dengan mengakui akan kehadiran Allah dalam ruang dan waktu kehidupan tanpa bisa dibatasi, manusia dapat memulai pencarian akan Dia di dalam ruang-cyber.

Masalahnya adalah apakah kehadiran atau keberadaan Allah dapat dimengerti dalam konsep-konsep manusia tentang "kehadiran" atau "keberadaan"? Terhadap pertanyaan itu, Gregory Palamas berpendapat bahwa Allah bukanlah sesuatu yang 'alami' atau 'ada' dalam pengertian Ia bisa diterima sebagai satu obyek yang ada di antara pluralitas keberadaan obyekobyek lain. Jika kita mengatakan 'Allah ada', maka kata 'ada' itu mengandung konotasi yang berbeda dengan penggunaannya pada hal-hal yang diciptakan. Palamas menyebut Allah sebagai hyperousios, 'melampaui yang ada', artinya, jika Allah 'bukanlah sesuatu' dalam pengertian Ia bukan salah satu di antara obyek-obyek yang ada, maka Ia adalah 'segala sesuatu' dalam arti, tanpa penyertaan yang terus menerus sebagai bentuk kuasa kreatifNya, tak ada kekuatan kreatif dalam diri manusia, bahkan tak ada manusia atau obyek ciptaan lain yang dapat ada dalam cara apapun. $^{33}$

Pendapat Byrne dan Palamas di atas memungkinkan pencarian akan kehadirannya dalam ruang dan waktu kehidupan manusia, termasuk dalam kenyataan virtual di ruang-cyber. Jika kita meyakini bahwa Allah tidak berhenti berkreasi, tetapi terus menerus berkreasi lewat kekuasaan dan kehadirannya, maka kita juga mesti menerima bahwa seluruh kreasi manusia yang menghidupkan turut dikreasikan olehNya.

Spiritualitas, seperti yang digambarkan oleh Perrin sebelumnya memuat empat elemen dasar, yaitu: (1) Kapasitas mendasar manusia untuk mencari makna, nilai, dan tujuan hidup; (2) untuk saling terhubung dengan sesama manusia dan seluruh ciptaan; (3) dalam jalan-jalan yang

http://www.ed.ac.uk/polopoly fs/1.22775!/fileManager/god\%2520in \%2520cyberspace.pdf, dilihat pada 18 Mei 2013.

${ }^{33}$ Kallistos Ware, God Immanent yet Transcendent: The Divine Energies according to Saint Gregory Palamas, dalam P. Clayton \& A. Peacocke (eds.), In Whom We Lives and Move and Have Our Being: Panentheistic Reflections on God's Presence in the World (MI: Grand Rapids, 2004), hlm. 162. 
dipilih. Ketiga aspek itu mesti dijelaskan lewat (4) studi/penelitian. Elemen-elemen itu cukup memudahkan upaya-upaya memahami spiritualitas (dalam) ruang-cyber.

Dengan demikian, spiritualitas (dalam) ruang-cyber dapat dibatasi dalam empat elemen sebagai berikut:

1. Seluruh upaya manusia untuk menemukan makna, nilai, dan tujuan hidup yang otentik dalam ruang-cyber/internet melalui interaksi-interaksi dengan data digital (orang lain, ide-ide, dan konsep-konsep spiritualitas);

2. Makna, nilai, dan tujuan hidup yang otentik itu dapat membimbingnya untuk berhubungan dengan sesama dan seluruh ciptaan yang lain, baik secara fisik maupun secara virtual;

3. Hubungan-hubungan itu terbangun dalam jalan-jalan hidup yang dipilih;

4. Ketiga aspek di atas mesti dapat dijelaskan lewat suatu penelitian.

\section{Tinjauan Metodologis}

Salah satu elemen yang membentuk definisi spiritualitas secara utuh sebagaimana yang disampaikan Perrin di atas adalah studi atau penelitian terhadap spiritualitas. ${ }^{34}$ Terhadap itu, pertanyaan-pertanyaan pengaruh yang dikemukakan di awal tulisan ini patut dikedepankan. Walaupun spiritualitas adalah sesuatu yang melampaui batas-batas keagamaan institusional, namun dalam refleksi ini, spiritualitas dimengerti dalam hubungan dengan keberagamaan manusia.

Dalam pengantar buku Religion and Cyberspace yang dieditori Morten T. Højsgaard dan Margit Warburg dinyatakan bahwa ada pergeseran fokus dalam studi akademik tentang agama dan internet. Mereka membahasakannya dalam istilah pergeseran dari gelombang pertama penelitian - yang memusatkan perhatian pada pesona, kebaruan, dan aspek-aspek luar biasa dari ruang-cyber - menuju gelombang kedua yang cenderung memberi tekanan pada perbedaanperbedaan dari bidang kajian itu dan kebutuhan untuk mendudukkan penemuan-penemuan baru dalam perspektif historis dan sosial yang lebih luas. Dalam gelombang pertama, internet dianggap dapat menciptakan agama-agama baru yang hanya tersedia dalam ruang-cyber. Teknologi informasi hadir untuk mentransformasi dunia kehidupan manusia. Sementara dalam gelombang kedua penelitian tentang agama dalam ruang-cyber, signifikansi dari jaringanjaringan komputer didudukkan dalam perspektif yang lebih realistis. ${ }^{35}$

Jika dalam pengantar buku Religion and Cyberspace dibuka dengan formulasi doa yang disebut sebagai doa cyberpunk's, yang strukturnya meniru struktur Doa Bapa Kami, maka pada awal tulisan ini dikutip formulasi pengakuan iman virtual yang strukturnya meniru struktur Pengakuan Iman Rasuli. Jika dianalisis dengan menggunakan pendekatan gelombang pertama penelitian, akan difokuskan pada kosakata baru di bidang teknologi informasi, gambaran yang

\footnotetext{
${ }^{34}$ Perrin menegaskan bahwa keingintahuan manusia telah membimbingnya untuk mencari jawab tentang bagaimana orang menghidupi realitas dalam aspek-aspek spiritualitas lain (tiga elemen pembentuk definisi spiritualitas di atas). Ia menganggap bahwa seluruh aspek kehidupan manusia dapat dibingkai dalam spiritualitas dan itu layak dijadikan sebagai bidang kajian yang serius dari studi-studi akademis. Ia menawarkan dua perspektif dalam menstudikan spiritualitas, pertama adalah pendekatan praktis dan formatif yang bertujuan untuk menjelaskan bagaimana orang melakukan sesuatu yang baik dengan landasan spiritualitasnya; kedua, adalah pendekatan teoretis yang bertujuan untuk menjelaskan dinamika kehidupan spiritual dalam hubungan dengan seluruh aspek kehidupan manusia dengan menggunakan metode-metode dari berbagai disiplin ilmu seperti psikologi, Antropologi, sosiologi, dan lainnya. Perrin (2007: 19).

${ }^{35}$ Højsgaard \& Warburg (2005: 8-9).
} 
anti-klerus dan sarkasme teks. Pendekatan gelombang kedua penelitian akan memusatkan perhatian pada fakta-fakta yang berkontribusi pada lahirnya pengakuan iman virtual di atas. ${ }^{36}$

Dalam terang dua gelombang penelitian terhadap agama dan ruang-cyber sebagaimana digambarkan di atas, maka beberapa hal terkait metodologi dapat dikemukakan. Studi terhadap spiritualitas dalam pandangan Perrin mensyaratkan prinsip-prinsip utama metodologis yang mesti dipahami dan dimiliki. ${ }^{37}$ Berdasarkan prinsip-prinsip itulah, refleksi metodologis ini dibangun, yaitu:

1. Memiliki pemahaman yang luas tentang spiritualitas:

Bagi Perrin, spiritualitas mesti dimengerti melampaui batas-batas konvensional agamaagama. Dalam pengertian itu, spiritualitas dihidupi dalam berbagai bidang seperti pendidikan, kesehatan, tempat kerja, dan lain-lain. Data-data dari bidang-bidang ini sangat dibutuhkan dalam rangka memahami spiritualitas (Kristen), begitu sebaliknya. Dengan demikian, spiritualitas pun mestinya dapat dimengerti terkait kehadirannya dalam ruang-cyber.

2. Memahami hubungan antara spiritualitas dan teologi:

Pada bagian ini, Perrin memusatkan pembahasan tentang spiritualitas Kristen. Dinyatakan bahwa sekalipun ada banyak cara pemaknaan tentang kehadiran Allah dalam seluruh aspek kehidupan manusia di segala masa dan tempat, semua cara itu adalah titik tolak bagi upaya memahami spiritualitas Kristen.

Dalam perspektif spiritualitas (dalam) ruang-cyber, teologi kontekstual mesti mendapatkan tempat. Teologi bukanlah diskursus tentang Allah, tetapi tentang konteks kehidupan manusia yang di dalamnya orang mengimani Allah. Dengan demikian, setiap teologi adalah teologi kontekstual karena hadir dalam ciri khas konteksnya masingmasing, atau ciri khas isu-isu yang menjadi pergumulannya. Dalam terang pemahaman itu, ruang-cyber adalah konteks berteologi.

3. Memahami pengalaman sebagai obyek studi:

Studi terhadap spiritualitas tentang pengalaman sebagai pengalaman. Artinya, seluruh pengalaman kehidupan manusia dapat dijadikan obyek studi spiritualitas.

Pada bagian ini, pengalaman peneliti terlibat di dalam ruang-cyber adalah hal yang tidak bisa ditawar. Masuk ke dalam ruang-cyber, terhubung dengan orang-orang lain, menemukan sumber-sumber tentang spiritualitas, termasuk pengalaman spiritualitas orang lain yang dikisahkan di sana, menceritakan pengalaman sendiri di dalam ruang itu, dan lain sebagainya, adalah contoh pengalaman cyber. Dengan demikian, pengalaman manusia yang saling terhubung dalam ruang-cyber pun dapat dijadikan sebagai obyek studi.

4. Memahami pentingnya konteks:

Tiap tempat dalam tiap waktu berbeda adalah unik. Upaya memahami kekhususankekhususannya itu adalah salah satu cara memahami bagaimana manusia hidup dalam spiritualitasnya.

Ruang-cyber adalah tempat (baru) yang unik dalam interaksi sesama manusia. Keunikannya terletak pada kehadirannya sebagai ruang simulasi, fiksi, dan imitasi bagi setiap individu yang saling terhubung dengan individu lainnya, atau dengan mesin itu

\footnotetext{
${ }^{36}$ Højsgaard \& Warburg (2005: 1-9).

${ }^{37}$ Perrin (2007: 11-13).
} 
sendiri. Dalam keunikannya itu, ia dapat dimengerti sebagai konteks bagi upaya pencarian makna dan nilai bagi kehidupan manusia.

5. Memiliki kesadaran sejarah:

Masa lalu mesti dipahami dalam hubungannya dengan masa kini dan masa depan. Dengan memiliki kesadaran budaya, tiap peneliti dapat melakukan penelitian tentang spiritualitas berangkat dari horizon budayanya masing-masing.

Ruang-cyber adalah horizon budaya yang baru yang telah merambah ke dalam seluruh horizon budaya masyarakat dunia. Kekristenan adalah salah satu horizon budaya dunia yang dapat menjadikan titik berangkat memahami spiritualitas (dalam) ruang-cyber, selain horizon-horizon lokal lainnya.

6. Pendekatan multidisiplin:

Prinsip utama menstudikan spiritualitas adalah multidisiplinaritas. Hal itu harus dimulai dengan menerima kenyataan bahwa tak ada satupun disiplin ilmu yang memiliki seluruh jawaban tentang kehidupan manusia. Tiap disiplin ilmu memberikan kontribusi masingmasing dari sudut pandangnya.

Terhadap spiritualitas (termasuk di dalamnya spiritualitas [dalam] ruang-cyber), dapat diteropong dari berbagai sudut, ekonomi, sosiologi, Antropologi, psikologi, teologi, filsafat, dan lain-lain.

7. Penguasaan terhadap pendekatan-pendekatan hermeneutika:

Metode-metode hermeneutika memberikan jalan bagi pencarian-pencarian makna, baik dari masa lalu, maupun dari tempat yang lain. Dengan penguasaan terhadapnya, peneliti dapat disadarkan bahwa meneliti spiritualitas bukan sekedar memberi informasi, tetapi juga mentransformasi.

\section{Penutup}

Generasi yang lahir di atas tahun 2000 adalah generasi teknologi informasi. Mereka, umumnya di perkotaan, dibesarkan dalam serbuan massif berbagai macam gadget sehingga tidak kekurangan pilihan untuk memperoleh informasi tentang apa saja. Teknologi informasi telah menjadi kebutuhan dan gaya hidup, tanpanya tak ada gaya, tanpanya mau mati rasanya. Hidup dengannya memberikan nuansa dan pengetahuan baru yang mengalir terus menerus, hidup dengannya lebih berarti daripada hidup tanpanya. Apakah ia telah menjadi semacam spiritualitas baru, seperti yang diungkapkan dalam pengakuan iman virtual di awal tulisan ini?

Dari sudut Halmahera, saya sadar bahwa ada berbagai kesenjangan yang terjadi, termasuk kesenjangan digital. Penguasaan terhadap teknologi komunikasi dan informasi adalah salah satu syarat kemajuan di tempat ini, di zaman ini, ketika referensi-referensi fisik semakin kurang laku, bahkan sulit ditemukan. Dari sudut Halmahera juga, kekayaan dalam ruang-cyber dapat dimanfaatkan sedemikian rupa agar menjadi kerangka kerja bagi upaya-upaya memaknai manusia yang terus berubah.

Tulisan ini dimulai dengan dua pertanyaan pengaruh: "Sejauhmana spiritualitas (dalam) ruang-cyber dapat distudikan atau diteliti oleh para teolog dan Mahasiswa teologi di Tobelo dan di mana saja yang tertarik terhadap isu-isu ini?" dan "Apa saja kemungkinan-kemungkinan metodologis yang tersedia, yang dapat mengarahkan studi atau penelitian semacam itu?" Jawaban-jawaban terhadap pertanyaan-pertanyaan itu telah coba diberikan dalam keacakan berpikir saya dengan memanfaatkan sebanyak mungkin sumber-sumber relevan yang mungkin 
diperoleh seperti tertulis di atas. Biarlah, dalam perspektif pluralitas penafsiran, para pembaca yang lebih mampu menafsir jawaban-jawaban itu bagi kepentingan pembaca.

Bagi saya, spiritualitas (dalam) ruang-cyber, layak diteliti sejauh ruang itu sendiri telah diakui sebagai konteks interaksi antar sesama manusia, walaupun interaksi itu adalah interaksi data (digital), bukan interaksi fisik. Dengan berhutang pada kontribusi-kontribusi para pemikir, ruang-cyber - yaitu gelombang penelitian pertama yang menganggap bahwa ruang-cyber telah mentransformasi kehidupan manusia, dan gelombang penelitian kedua yang memandang setiap penemuan-penemuan baru di bidang teknologi informasi dan komunikasi mesti didudukkan dalam spektrum perspektif yang lebih realistis - sebagai titik berangkat untuk memahami topik ini. Selain itu, beberapa aspek utama metodologis telah ditawarkan sebagai pegangan bagi setiap teologi, mahasiswa teologi, atau pembaca teologi, baik di Halmahera maupun di mana saja, yang ingin lebih jauh memahami tentang topik di atas.

Akhirnya, menyitir pepatah lama, "tiada gading yang tak retak", tulisan ini dipersembahkan terbuka ke hadapan pembaca untuk ditafsir. Tafsiran-tafsiran yang dilakukan terhadapnya dapat saja memunculkan banyak masalah, baik terhadap sistematika berpikir, isi, tujuan dan manfaat, serta hal-hal lain yang belum sempat terolah dari sumber-sumber dalam ruang-cyber yang begitu kaya. Diskusi adalah salah satu wadah untuk saling mengkritik dan memberikan insight lain tentang topik ini. Saya secara pribadi sangat terbuka terhadap kemungkinan-kemungkinan itu, karenanya ruang-ruang diskusi selalu terbuka dengan menghubungi saya dalam ruang-cyber di Facebook dengan id: "JusNick Anamofa" atau lewat alamat e-mail: janamova@yahoo.com". Semoga bermanfaat bagi seluruh proses pencarian makna dalam kehidupan kita.

\section{Referensi}

Anamofa, Jusuf Nikolas, Analisis Filosofis Terhadap Teoblogis: Relevansinya Sebagai Penyeimbang Moralitas dalam Masyarakat Internet, dalam UNIERA - Jurnal Ilmiah Lintas Ilmu Vol. 1, No. 2, Agustus 2012, hlm. 101-102.

Benedikt, Michael, Introduction to Cyberspace: First Steps, sumber https://pdfs.semanticscholar.org/8517/59b84ee29d8fd9ee66b90316e4bc08406e15.pdf, dilihat pada 17 Mei 2013.

Bryant, Rebecca, What Kind of Space is Cyberspace, dalam Minerva, An Internet Journal of Philosophy 5 (2001), hlm. 138-55. Sumber http://www.minerva.mic.ul.ie/vol5/cyberspace.pdf, dilihat pada 12 Mei 2013.

Buick \& Joran Jevic, 1997, Mengenal Cyberspace For Beginners, Bandung: Mizan.

Byrne, Lavinia, 2000, God in Cyberspace. http://www.ed.ac.uk/polopoly_fs/1.22775!/fileManager/god\%2520in_\%2520cyberspac e.pdf, dilihat pada 18 Mei 2013.

Clayton, P. \& A. Peacocke (eds.), 2004, In Whom We Lives and Move and Have Our Being: Panentheistic Reflections on God's Presence in the World, MI: Grand Rapids.

Gernon, Pierre, A Sketch of an Ontology of Spaces, sumber http://kmi.open.ac.uk/events/onespace08/docs/onespace2008_submission_2.pdf, dilihat pada 12 Mei 2013.

Højsgaard, Morten T. \& Margit Warburg (eds.), 2005, Religion and Cyberspace, London \& NY: Routledge.

Mabry, John, Cyberspace and the Dream of Teilhard de Chardin, dalam http://www.watershedonline.ca/roots/chardin/chardin2.html, dilihat pada 13 Mei 2013. 
Perrin, David B., 2007, Studying Christian Spirituality, New York: Routledge.

Piliang, Yasraf Amir, 2010, Dunia Yang Dilipat: Tamasya Melampaui Batas-Batas Kebudayaan (ed. 3), Bandung: Matahari.

Stout, Danniel A. (ed.), 2006, Encyclopedia of Religion, Communication, and Media, New York: Routledge.

Wertheim, Margareth, Is Cyberspace a Spiritual Space?, dalam http://www.cybersociology.com/files/7_wertheim.html, dilihat pada 17 Mei 2013.

Wiegand, Greg (ed.), 2002, Encyclopedia of Technological Terms, Indianapolis: Que Publishing. Zijderveld, Theo, 2008, Cyberpilgrims: The Construction of Spiritual Identity in Cyberspace (Research Master Theology), sumber http://www.theozijderveld.com/cyberpilgrims/_Cyberpilgrims theo_zijderveld.pdf, dilihat pada 12 Mei 2013.

http://id.m.wikipedia.org/wiki/Daftar_istilah_Internet_Indonesia.htm, dilihat pada 12 Mei 2013. http://en.wikipedia.org/wiki/Digital_divide, dilihat pada 16 Mei 2013.

http://besar.blog.fisip-untirta.ac.id/2013/03/16/digital-divide-dan-e-literacy/, dilihat pada 16 Mei 2013.

Kompas.com, Internet Butuh Tombol "Delete”, 10 Mei 2013.

Tempo.com, iPad Bikin Anak Malas Membaca, 17 Mei 2013.

KBBI Android. 